\title{
BCC metastasis: a very rare sequela of a common disease- a case report documenting lymphatic invasion and a literature review
}

\author{
Mohammad Mohammad, Katharina Schumacher 두, Rakhee Nayar, Jonathan Morton
}

Plastic Surgery, Whiston Hospital, Prescot, UK

\section{Correspondence to \\ Dr Mohammad Mohammad; dr.mohammadesmail@gmail.} com

Accepted 9 November 2020

\section{DESCRIPTION}

Basal cell carcinoma (BCC) is the most common skin cancer worldwide, accounting for approximately $80 \%$ of non-melanoma skin cancers. BCC metastasis is an extremely rare sequela with an estimated incidence of $0.0028 \%-0.5 \%$ among all BCC diagnoses.

We describe a case of an 82-year-old man with a history of multiple previous BCC excisions. Comorbidities included chronic obstructive pulmonary disease and transient ischaemic attacks. His medications included aspirin, dipyridamole, lansoprazole, perindopril, salbutamol, fluticasone with salmeterol, amlodipine and simvastatin.

$\mathrm{He}$ was referred to the Mohs surgical service at the Mersey Regional Plastic Surgery Unit with a $15 \mathrm{~mm}$ sclerosing lesion on his right temple, which had been present for some years. There was no palpable regional lymphadenopathy. Biopsy confirmed morphoeic BCC. The patient underwent Mohs micrographical excision of the lesion with same day reconstruction. For those unfamiliar with the procedure, our standard Mohs technique involves immediate preparation of the specimen with colour coding, embedding in cryomatrix, horizontal sectioning and staining. ${ }^{1}$ This allows for same day examination of $100 \%$ of the surgical margin by both the Mohs surgeon and a consultant pathologist. This histopathology examination

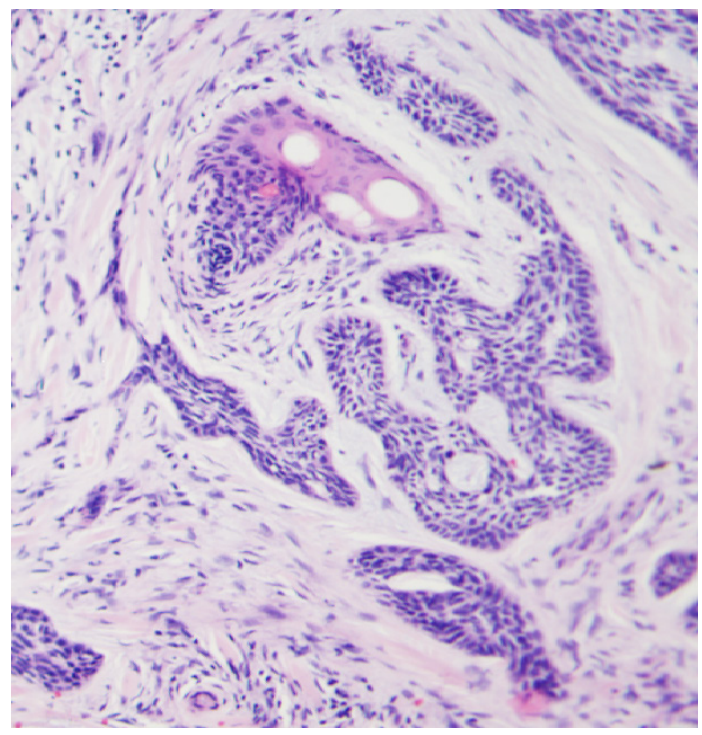

Figure 1 A photomicrograph showing the main lesion paraffin section $\times 20$.

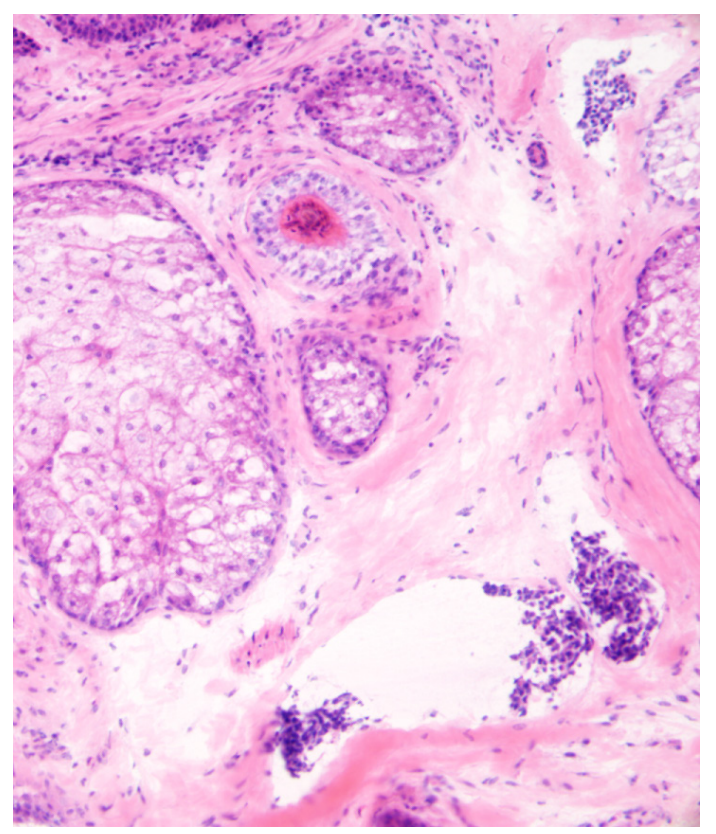

Figure 2 A photomicrograph showing a frozen section histopathology slide demonstrating basal cell carcinoma clusters invading lymphatic vessels. Local Docs/(http:/ casereports.bmj.com/instructions-for-authors/copyright. pdf).

revealed two apparent clusters of BCC lying within a lymphatic channel. The slides were re-examined by three senior histopathologists and the lymphatic invasion confirmed (figures 1 and 2). No basosquamous differentiation was identified. The case was discussed in the regional specialist skin cancer multidisciplinary team meeting. He underwent adjuvant radiotherapy with 5-year follow-up planned. At 18 months postsurgery, the patient remains well with no evidence of metastasis.

A literature review was undertaken with support from the clinical library service at St Helens and Knowsley Teaching Hospitals National Health Service Trust. This found less than 300 case reports of metastatic BCC. ${ }^{2}$ To our knowledge, this is the first published photomicrograph of actual BCC clusters in a vessel lumen. There is evidence that metastatic BCC is linked to poor prognosis with a mean survival of 8 months. Spread is almost invariably lymphatic, with regional lymphadenopathy the most common development. No long-term follow-up was described in the available literature.

Metastatic BCC, although exceedingly rare, is a serious complication that needs to be considered 
during the clinical examination, counselling, education, histopathological examination and follow-up of the patient.

Radiotherapy and Hedgehog signalling pathway inhibitors (eg, vismodegib) have both been used to manage metastatic BCC.

\section{Learning points}

Metastatic basal cell carcinoma (BCC) is a rare but potentially serious sequela of BCC.

- Metastatic BCC is associated with poor prognosis.

- Metastatic BCC should be kept in mind throughout the management especially with regards to clinical examination, histological examination and patient counselling.

Acknowledgements Special thank you to our medical library team at St Helens and Knowsley NHS Foundation Trust. We would like to acknowledge histopathology consultants: Dr Naveen Sharma. Dr Leigh Forsyth. Dr Hannah Davies. And Dr Omar Asmar for his contribution to this work.
Contributors MEHEM: design, critical appraisal, review, final approval. KS: critical appraisal, review RN: supervision. JM: supervision.

Funding The authors have not declared a specific grant for this research from any funding agency in the public, commercial or not-for-profit sectors.

Competing interests None declared.

Patient consent for publication Obtained.

Provenance and peer review Not commissioned; externally peer reviewed.

\section{ORCID iD}

Katharina Schumacher http://orcid.org/0000-0001-5096-3866

\section{REFERENCES}

1 Salopek T, McKinnon G, Kurwa H. Mohs micrographic surgery. Alberta, Canada: Alberta Health services, 2019. https://www.albertahealthservices.ca/assets/info/hp/cancer/ifhp-cancer-guide-cu017-mohs.pdf

2 Tang S, Thompson S, Smee R. Metastatic basal cell carcinoma: case series and review of the literature. New South Wales, Australia. The Australasian Journal of Dermatology 2017 https://pubmed.ncbi.nlm.nih.gov/26916335/

3 Aydin D, Hölmich LR, Jakobsen LP. Metastatic basal cell carcinoma caused by carcinoma misdiagnosed as acne-case report and literature review. Copenhagen, Denmark: Clinical Case Reports, 2016: 601-4.

Copyright 2020 BMJ Publishing Group. All rights reserved. For permission to reuse any of this content visit

https://www.bmj.com/company/products-services/rights-and-licensing/permissions/

BMJ Case Report Fellows may re-use this article for personal use and teaching without any further permission.

Become a Fellow of BMJ Case Reports today and you can:

- Submit as many cases as you like

- Enjoy fast sympathetic peer review and rapid publication of accepted articles

- Access all the published articles

Re-use any of the published material for personal use and teaching without further permission

\section{Customer Service}

If you have any further queries about your subscription, please contact our customer services team on +44 (0) 2071111105 or via email at support@bmj.com.

Visit casereports.bmj.com for more articles like this and to become a Fellow 